\title{
Preparation and Properties of Anti-Nail-Biting Lacquers Containing Shellac and Bitter Herbal Extract
}

\author{
Chutima Limmatvapirat $\mathbb{D}^{1},{ }^{1}$ Sontaya Limmatvapirat, ${ }^{2}$ Siraprapa Chansatidkosol, ${ }^{2}$ \\ Wantanwa Krongrawa, ${ }^{2}$ Napasorn Liampipat, ${ }^{2}$ Sarocha Leechaiwat, ${ }^{2}$ Patipat Lamaisri, ${ }^{2}$ \\ Lawan Siangjong, ${ }^{3}$ Paranee Meetam, ${ }^{3}$ and Kuntontip Tiankittumrong ${ }^{4}$ \\ ${ }^{1}$ Department of Pharmaceutical Chemistry, Faculty of Pharmacy, Silpakorn University, Nakhon Pathom 73000, Thailand \\ ${ }^{2}$ Department of Pharmaceutical Technology, Faculty of Pharmacy, Silpakorn University, Nakhon Pathom 73000, Thailand \\ ${ }^{3}$ Department of Biopharmacy, Faculty of Pharmacy, Silpakorn University, Nakhon Pathom 73000, Thailand \\ ${ }^{4}$ H. A. Plus Co., Ltd., 7 Moo 10 Phuchaosamingprai Road, Samrongtai, Prapradang, Samutprakan 10130, Thailand
}

Correspondence should be addressed to Chutima Limmatvapirat; limmatvapirat_c@su.ac.th

Received 23 August 2021; Revised 19 October 2021; Accepted 30 October 2021; Published 16 November 2021

Academic Editor: Atsushi Sudo

Copyright (C) 2021 Chutima Limmatvapirat et al. This is an open access article distributed under the Creative Commons Attribution License, which permits unrestricted use, distribution, and reproduction in any medium, provided the original work is properly cited.

The purpose of the present investigation was to formulate and evaluate anti-nail-biting lacquers consisting of bitter herbal extracts. The hydroalcoholic extracts obtained from Andrographis paniculata and Tinospora crispa were determined for phytochemical constituents, total phenolic contents, antioxidant activities, anti-inflammatory activities, and cytotoxicities. Antinail-biting lacquers were prepared by using herbal extracts (bittering agent), shellac (film forming polymer), ethanol (volatile solvent), and other indispensable additives with continuous stirring. Thus, attempts to enhance the film property and bitterness are accomplished by using polyvinylpyrrolidone (PVP K30) as a copolymer and varying concentrations of herbal extracts. Good accepted formulations were established for drying time, $\mathrm{pH}$, viscosity, smoothness of film, film strength, water resistant, and solubility in simulated saliva and evaluated their bitterness in human volunteers. The results revealed that phytochemical constituents including tannins, glycosides, reducing sugars, alkaloids, terpenoids, and flavonoids were found present in both extracts while saponins were only detected in A. paniculata extract. Although T. crispa extract exhibited a significantly higher $(p<0.05)$ total phenolic content and antioxidant activity than $A$. paniculata extract, it showed lower protein denaturation inhibition property than A. paniculata extract. Because of the potentials of both extracts without cytotoxicity, anti-nail-biting lacquers containing either A. paniculata extract or T. crispa extract were developed and evaluated. Drying time of formulations was 6-11 min with visually seen glossiness of formulation. Formulations of the nail lacquer showed good $\mathrm{pH}$, viscosity, smoothness of film, film strength, water resistant, and solubility in simulated saliva. The formulations displaying no significant cytotoxicity effect on CRL-2076 cells were assessed on healthy human volunteers to compare bitterness and film characteristics. The results revealed that the optimized formulation containing A. paniculata extract could successfully achieve good film forming property and bitterness release which is considered promising for stopping nail biting.

\section{Introduction}

Onychophagia (nail biting) means putting one or several fingers in the mouth and biting on nail with teeth. It is a chronic behavioral disorder in children and adults that commonly cooccur with thumb and finger sucking [1]. These behaviors probably associated with psychiatric disorders can cause paronychia, onycholysis, onychomycosis, gingivitis, temporomandibular dysfunction, oral carriage of Enterobacteriaceae, parasitic infection, and some negative social impacts [2-5].

There are several approaches to cease from nail biting and finger sucking, such as painting a bitter tasting lacquer containing denatonium benzoate and sucrose octa-acetate onto the nails [2] and utilizing a nonremovable reminder, e.g., wristband, finger guard, and glove [6]. However, bitter 
nail lacquers containing denatonium benzoate or sucrose octa-acetate for utilize as nail-biting and thumb-sucking deterrents cannot be generally recognized as safe and effective because there is lack of information acquired from adequate and well-controlled, double-blind studies [7]. As in the previous study, although the method of applying a distasteful lacquer exhibited higher drop-out rate than the method of wearing a nonremovable reminder, it was more effective to quit the nail-biting habit by examining only nondropouts [6]. The study indicated that the bitter nail lacquer was a potential alternative to prevent the nail-biting habit due to its long-lasting efficacy of coatings, patient compliance, and success with treatment.

As in earlier studies, the pitfalls of classical anti-nailbiting lacquers were unclear toxicity of synthetic polymers and bitter substances, apply several times daily due to easy to wash off, and cross contamination of nail lacquers during cooking and eating [6]. Consequently, the innovative antinail-biting lacquers mainly composed of natural edible ingredients have been developed in order to reduce the toxicity, enhance bitterness, improve water resistance and dissolution in simulated saliva, and also increase other biological properties, especially antioxidant and anti-inflammatory activities.

A chronic habit of nail biting or finger sucking causes dry and peeling skin and leads to inflammation of the skin surrounding the nail [8]. Plenty of unpalatable herbs grown throughout Southern and Southeastern Asia exhibited various biological effects, especially antioxidant and antiinflammatory activities. Andrographis paniculata, commonly known as king of bitters, was found to possess antioxidant activities associated with an increase in the activity of antioxidant enzymes including catalase, glutathione S-transferase, and superoxide dismutase [9]. It could also safeguard cutaneous cells from inflammation [10]. Tinospora crispa was reported to have antioxidant activity through radical scavenging and metal chelating mechanisms and antiinflammatory activity via increasing intracellular expressions of cytokine, INF-g, IL-6, and IL-8 [11]. Antioxidant and antiinflammatory activities of extracts from A. paniculata and $T$. crispa were associated with the contents of phenolics and other phytochemicals $[9,11]$. In this study, herbal extracts obtained from $A$. paniculata and T. crispa were selected as active ingredients in anti-nail-biting lacquers because of their bitterness and biological activities. One purpose of this study was to determine antioxidant and anti-inflammatory activities of selected herbal extracts.

A coating of nail lacquer can protect thin, friable, vulnerable, and irregular nails along with giving a sustainable exterior layer in order to make them look stronger and more beautiful [12]. The chemical properties of nail lacquers are established on polymerization, evaporation, and adhesion [13]. Monomers form strong bonds with other molecules through polymerization reactions resulting cross-linking of polymer films. After applying a nail lacquer, a solid polymer film is formed by solvent evaporation. A film forming polymer can adhere to the nail plate.

Nail lacquers generally consist of film-forming polymers, volatile solvents, plasticizing agents, and dyes [14, 15]. Coat- ing formulas often contain pliable resins so as to amplify adhesion and offer glossy appearance. Because of optimum drying time, solvents including ethyl acetate, butyl acetate, and isopropyl alcohol are normally employed for dissolving various resins and other components of nail lacquers $[15,16]$. Plasticizers such as camphor, triphenyl phosphate, trimethyl pentanyl diisobutyrate, and acetyl tributyl citrate can enhance flexibility and durability to the films. Dyes or colorants are coloring substances dissolved in nail lacquers and adsorbed onto the nail plates to which they are applied [14, 15].

With regard to help people safely utilize nail lacquers, it is important to study the materials engaged in the production of nail lacquers. Synthetic resins (e.g., toluenesulfonamideformaldehyde, polyvinyl butyral, and polyester resins) may lead to paronychia, onycholysis, and onychodystrophy [17]. Toxic plasticizers (e.g., phthalate and organophosphate) and harmful solvents (e.g., toluene and formaldehyde) have been prohibited or restricted from use in nail lacquers because of their adverse effects on skin, reproductive system, embryonic development, thyroid gland, and central nervous system [18]. People may have a considerable risk of being exposed to detrimental polymers, plasticizers, and solvents in nail lacquers especially if they are swallowed. Therefore, this study was carefully selected the safe ingredients, aiming for the safety and quality of nail lacquers.

Natural lac is a resin secreted by lac insects (e.g., Laccifer lacca Kerr and Kerria lacca) [19]. Seed lac derived from stick lac is processed into shellac, a natural gum resin, by handcrafted, heat, or solvent methods. The special properties of shellac include energetically favorable adhesion to the surface, water protection, and shimmering appearance. Furthermore, shellac has been accepted by US Food and Drug Administration (US FDA) and European Food Safety Authority (EFSA) to utilize in pharmaceuticals and food $[19,20]$. According to the consumer product safety, synthetic resins have been superseded by durable natural polymers, especially shellac, which could be developed to improve drying time, adhesiveness, and flexibility of nail lacquers [15]. In case of solvent selection, ethanol could be employed as a solvent in nail lacquers because of its rather low toxicity compared with other organic solvents used for nail lacquers and efficacy to dissolve various active constituents in herbal extracts.

The objective of this study was to develop nontoxic antinail-biting lacquers containing bitter herbal extracts obtained from $A$. paniculata and T. crispa. Not only the selection of ingredients but also the evaluation of products is essential for product safety and quality. Therefore, this study was invented to determine the quality control parameters (e.g., drying time, $\mathrm{pH}$, viscosity, smoothness of film, film strength, water resistant, and solubility in simulated saliva) of formulated nail lacquers and then evaluate the bitterness in human volunteers.

\section{Materials and Methods}

2.1. Materials. Ethanol was supplied by Thai Food and Chemical Co., Ltd., Bangkok, Thailand. All chemicals 
utilized in phytochemical screening were of analytical grade purchased from Sigma-Aldrich Corporation (Missouri, USA). Potassium bromide, FTIR grade, attained from Thermo Fisher Scientific (Massachusetts, USA). FolinCiocalteu was purchased from Loba Chemie (Mumbai, India). Gallic acid, sodium carbonate, 2,2-diphenyl-1-picrylhydrazyl (DPPH), 2,4,6-tris(2-pyridyl)-s-triazine (TPTZ), acetate buffer, ferric chloride hexahydrate, and bovine serum albumin were procured from Sigma-Aldrich Corporation (Missouri, USA). L-Ascorbic acid was obtained from Chem-Supply Pty Ltd. (Gillman, South Australia). Ultrapure water generated by GenPure equipment (TKA Wasseraufbereitungssysteme $\mathrm{GmbH}$, Niederelbert, Germany) and ICP multielement standard solution XIII obtained from Agilent Technologies (Santa Clara, USA) were utilized to determine heavy metal contents. Diclofenac diethylamine and microbiological media were acquired from Merck KGaA (Darmstadt, Germany). Iscove's Modified Dulbecco's Media (IMDM), fetal bovine serum (FBS), 3-(4,5-dimethylthiazol2-yl)-2,5-diphenyltetrazolium bromide (MTT), and dimethyl sulfoxide (DMSO) were purchased from SigmaAldrich Corporation (Missouri, USA). Dewaxed bleached shellac and polyvinylpyrrolidone (PVP K30) USP were procured from Union Shellac Part., Ltd. (Bangkok, Thailand) and Shanghai Yuking Chemtech Co., Ltd. established by China Functional Polymer Industry Committee (Shanghai, China), respectively.

2.2. Extraction of Plant Materials. The dried aerial parts of $A$. paniculata and stems of T. crispa (Figure 1) were collected from gardens in Nakhon Pathom, Thailand, in April 2020. Both plant specimens were substantiated using the key to species and description in the Botanical Garden Organization (BGO) plant database, Ministry of Natural Resource and Environment, Thailand [21]. Voucher specimens were deposited in the Faculty of Pharmacy, Silpakorn University, Thailand. Samples were separately ground into fine particles and sieved to obtain the particle size $<0.149 \mathrm{~mm}$. Each sample was then macerated two times in $95 \% v / v$ ethanol at dried sample-to-solvent ratio of $1: 5 \mathrm{~g} / \mathrm{ml}$, maceration time of $3 \mathrm{~d}$, and maceration temperature of $25 \pm 1^{\circ} \mathrm{C}$ with periodic agitation. The mixtures were independently filtered using Whatman no. 1 filter paper to collect the filtrates for subsequent evaporation of solvents using a rotary evaporator (R100 , Buchi, Japan) under reduced pressure at $45^{\circ} \mathrm{C}$ to obtain A. paniculata and T. crispa ethanolic extracts. The extracts were dried to constant weight in a hot air oven (Heraeus, Hanau, Germany) at $50 \pm 5^{\circ} \mathrm{C}$ and kept at $-20^{\circ} \mathrm{C}$ until used.

2.3. Phytochemical Investigation. Preliminary phytochemical screening tests in the $10 \mathrm{mg} / \mathrm{ml}$ ethanolic solutions of $A$. paniculata and T. crispa extracts were accomplished using the standard methods [22-25]. All chemical tests were executed in triplicate.

2.3.1. Tests for Tannins [22, 23, 25]. For ferric chloride test, several drops of $10 \% \mathrm{w} / v$ ferric chloride solution were added to the sample solution. A brownish green color indicates the existence of tannins.
For lead acetate test, a few drops of $10 \% w / v$ lead acetate were added to the sample solution. The white precipitate was formed designating the presence of tannins.

2.3.2. Tests for Glycosides [22]. $2 \mathrm{ml}$ of glacial acetic acid and $1 \mathrm{ml}$ of ferric chloride were transferred into $1 \mathrm{ml}$ of sample solution, and then, $1 \mathrm{ml}$ of concentrated sulfuric acid was added. The appearance of blue-green color represents the presence of glycosides.

2.3.3. Tests of Reducing Sugars [22, 24, 25]. Ten drops of each solution A and B were added to a test tube containing $2 \mathrm{ml}$ of sample solution. After heating for $15 \mathrm{~min}$ at $60 \pm 0.5^{\circ} \mathrm{C}$, orange red precipitate or green suspension was formed stipulating the existence of reducing sugars.

2.3.4. Tests of Alkaloids [22-25]. For Dragendorff's test, the sample solution was acidified with diluted hydrochloric acid. The mixture was heated on a water bath and then filtered through a Whatman no. 1 filter paper. Equal volumes of the resulting solution and Dragendorff's reagent were reacted. The formation of an orange red precipitate indicates the existence of alkaloids.

For Mayer's test, equal volumes of the resulting solution and Meyer's reagent were mixed. The turbidity or a yellow precipitate indicates the presence of alkaloids.

2.3.5. Tests of Saponins [22-25]. For frothing test, $5 \mathrm{ml}$ of distilled water was added to a test tube containing $2 \mathrm{ml}$ of sample solution. The mixture was shaken for $5 \mathrm{~min}$ to observe the formation of $1 \mathrm{~cm}$ thick layer of stable liquid foams.

2.3.6. Tests of Terpenoids [22, 23, 25]. $1.5 \mathrm{ml}$ of sample solution was mixed with $1 \mathrm{ml}$ of chloroform, and then, $1 \mathrm{ml}$ of concentrated sulfuric acid was slowly added to form a reddish-brown layer at the junction specifying the presence of terpenoids.

2.3.7. Tests for Flavonoids [22-25]. For ferric chloride test, $2 \mathrm{ml}$ of sample solution was treated with $1 \mathrm{ml}$ of $10 \% \mathrm{w} / \mathrm{v}$ ferric chloride solution. Formation of a wooly brownish precipitate indicates the presence of flavonoids.

For Shinoda's test, $1.5 \mathrm{ml}$ of sample solution was treated with $1 \mathrm{ml}$ of methanol. The solution was warmed, and magnesium ribbons were added. 5 drops of concentrated hydrochloric acid were carefully added, and orange or red color was observed for flavonoids.

2.3.8. Tests for Steroids [22, 25]. $1.5 \mathrm{ml}$ of chloroform was mixed with $1.5 \mathrm{ml}$ of sample solution. $0.5 \mathrm{ml}$ of acetic anhydride and $1 \mathrm{ml}$ of $10 \% \mathrm{w} / \mathrm{v}$ sodium hydroxide solution were added. After mixing and standing for $10 \mathrm{~min}$, the appearance of a blue-green ring indicates the presence of steroids.

2.4. Fourier-Transform Infrared Spectroscopy (FTIR) Analysis. With regard to produce potassium bromide $(\mathrm{KBr})$ pellets of A. paniculata and T. crispa extracts, approximately 2 to $3 \mathrm{mg}$ of each dried extract was amalgamated with $100 \mathrm{mg}$ of dried $\mathrm{KBr}$ using a mortar and pestle, and then, the $\mathrm{KBr}$ /extract mixture was compressed into a thin transparent disc under a hydraulic press. The characteristic 


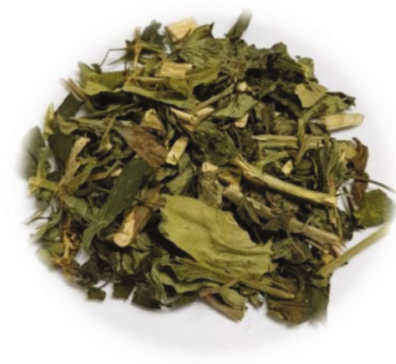

(a)

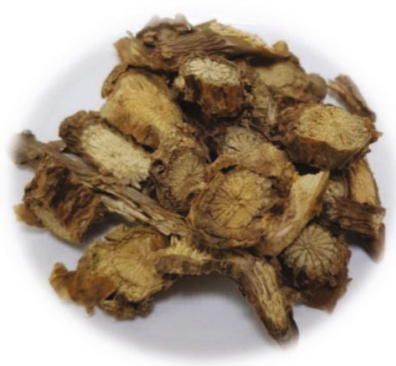

(b)

Figure 1: Dried aerial parts of A. paniculata (a) and stems of T. crispa (b).

functional groups of both extracts were analyzed using a FTIR spectrometer (Thermo Electron Scientific Instruments Corporation, Madison, WI, USA) at the frequency region of $4000-400 \mathrm{~cm}^{-1}$.

2.5. Total Phenolic Contents. Total phenolic contents of A. paniculata and T. crispa extracts were ascertained as $\mathrm{mg}$ of gallic acid equivalents per $\mathrm{g}$ of dried extract (mg GAE/g dried extract), in consonance with an improved FolinCiocalteu method [26]. A standard curve was created using gallic acid solutions which dissolved in methanol at concentrations between 20 and $100 \mu \mathrm{g} / \mathrm{ml}$. For sample estimation, $50 \mu \mathrm{l}$ of $1 \mathrm{mg} / \mathrm{ml}$ extract solution was completely mixed with $50 \mu \mathrm{l}$ of $50 \% v / v$ Folin-Ciocalteu reagent at $25 \pm 1^{\circ} \mathrm{C}$ for $5 \mathrm{~min}$. The solution was combined with $100 \mu \mathrm{l}$ of $7.5 \% \mathrm{w} / \mathrm{v}$ sodium carbonate solution and then incubated in the dark for $90 \mathrm{~min}$ at the same temperature. The absorbance at $765 \mathrm{~nm}$ wavelength was measured using a UV-visible spectrophotometer (Model U-2990, Hitachi, Japan).

\subsection{Antioxidant Activities}

2.6.1. DPPH Assay. Free radical scavenging activities of samples were assessed by a modified DPPH method [26]. L-Ascorbic acid in methanol was employed as a positive control, and scavenging activities of samples were evaluated using their calibration curves and expressed as $\mathrm{SC}_{50}$ values $(\mu \mathrm{g} / \mathrm{ml})$, the concentration required to reduce the initial DPPH radical concentration by $50 \%$. A volume of $300 \mu \mathrm{l}$ of each sample solution at various concentrations from 1.25 to $10 \mathrm{mg} / \mathrm{ml}$ in methanol was pipetted into $2.7 \mathrm{ml}$ of $0.5 \mathrm{mM}$ DPPH methanolic solution. After mixing, the solutions were allowed to stand in the dark for $30 \mathrm{~min}$ at 25 $\pm 1^{\circ} \mathrm{C}$. Absorbance values of solutions were read against a methanol blank at $515 \mathrm{~nm}$ using a UV-visible spectrophotometer (Model U-2990, Hitachi, Japan). The measurements were conducted in triplicate.

2.6.2. FRAP Assay. Ferric reducing antioxidant power (FRAP) assay was carried out in keeping with our foregoing report [26]. In short, the FRAP reagent consisted of $10 \mathrm{mM}$ TPTZ in $40 \mathrm{mM}$ hydrochloric acid, $20 \mathrm{mM}$ ferric chloride hexahydrate in ultrapure water, and $0.3 \mathrm{M}$ acetate buffer (pH3.6) in the volume ratio of $1: 1: 10$. A volume of $90 \mu \mathrm{l}$ of FRAP reagent was incubated with $30 \mu \mathrm{l}$ of $1 \mathrm{mg} / \mathrm{ml}$ sample solution in 96 -well plates in the dark at $37 \pm 1^{\circ} \mathrm{C}$ for $30 \mathrm{~min}$.
The absorbance values determined at $593 \mathrm{~nm}$ using a multimode microplate reader $\left(\mathrm{VICTOR}^{\circledR} \mathrm{Nivo}^{\mathrm{TM}}\right.$, Perkin Elmer, UK) were calculated by subtracting a reagent blank value. L-Ascorbic acid dissolved in methanol was used as a positive control, and all determinations were attained in triplicate. FRAP values were expressed as micrograms of ascorbic acid equivalent per gram of a dried extract $(\mu \mathrm{g} \mathrm{AAE} / \mathrm{g}$ dried extract).

2.7. Anti-inflammatory Activities. Inhibition of protein denaturation was determined according to our previous procedure [27], and the inhibitory activities were expressed as $\mathrm{IC}_{50}(\mathrm{mg} / \mathrm{ml})$, the concentration of the extract producing $50 \%$ inhibition of the protein denaturation. Briefly, the reaction mixture was comprised of $0.2 \mathrm{ml}$ of fresh egg albumin, $2.8 \mathrm{ml}$ of phosphate buffered saline (pH 7.4), and $2 \mathrm{ml}$ of sample solution with a concentration range varying between 0.2 and $4 \mathrm{mg} / \mathrm{ml}$. All mixtures were incubated at $37^{\circ} \mathrm{C} \pm 1^{\circ} \mathrm{C}$ for $15 \mathrm{~min}$ and then heated at $70 \pm 1^{\circ} \mathrm{C}$ for $5 \mathrm{~min}$. After cooling to room temperature, the absorbance values were determined at $660 \mathrm{~nm}$ using a UV-visible spectrophotometer (Model U-2990, Hitachi, Japan). Ultrapure water and diclofenac diethylamine were performed as negative and positive controls, respectively.

2.8. Quantification of Heavy Metals. After nitric acid assisted closed vessel microwave digestion, the concentrations of arsenic (As), cadmium (Cd), mercury $(\mathrm{Hg})$, and lead $(\mathrm{Pb})$ in samples were analyzed by inductively coupled plasmamass spectrometry (ICP-MS) as described in our previous report [26]. The standard solutions at five different concentrations used for establishing the calibration curves for heavy metals were prepared by diluting an ICP multielement standard solution XIII with $5 \% v / v$ nitric acid solution. All samples were digested by a microwave digester (Model ETHOS ONE, Milestone Corporation, Sorisole, Italy) and determined by an ICP-MS spectrometer (Model 7500ce, Agilent Technologies, Santa Clara, USA) in triplicate.

2.9. Microbial Limit Test. The microbiological examination including total aerobic mesophilic microorganisms (bacteria, yeast, and molds), Pseudomonas aeruginosa, Staphylococcus aureus, Candida albicans, and Clostridium spp. was done in accordance with the microbial enumeration test of the United States Pharmacopeia (USP) 41 [28]. 
2.10. Evaluation of the Cytotoxicities of Bitter Extracts and Nail Lacquers Containing Bitter Extract on Human Dermal Fibroblasts. The cellular viability of human dermal fibroblasts was evaluated upon treatment with either bitter extract or bitter nail lacquer using MTT colorimetric assay [29]. ATCC ${ }^{\circledR}$ CRL-2076 cells (Manassas, VA, USA) were seeded at density of $1 \times 10^{4}$ cells/well in a 96 well plate and incubated with $100 \mu \mathrm{l}$ supplemented IMDM until the confluency reached $80-90 \%$. Samples were separately serially diluted with IMDM to obtain the appropriate concentration ranges for testing. After treatments, the cells were incubated for $24 \mathrm{~h}$ at $37^{\circ} \mathrm{C}, 5 \% \mathrm{CO}_{2} .10 \mu \mathrm{l}$ of MTT solution $(5 \mathrm{mg} / \mathrm{ml})$ was put into each well and incubated at $37^{\circ} \mathrm{C}$ for $2 \mathrm{~h}$. The solution was then removed, and $100 \mu$ l of DMSO was subsequently added to dissolve the formazan crystals, which are generated by mitochondria of viable cells. The absorbance was measured at $550 \mathrm{~nm}$ using a fusion universal microplate analyzer (Model A153601, Packard BioScience Company, Connecticut, USA), and the percentages of cell viability were calculated compared with untreated controls.

\subsection{Formulation of Nail Lacquers}

2.11.1. Preparation of Extract-Free Nail Lacquers. Filmforming solutions with various concentrations $(10,15,20$, 25 , and $30 \% w / w)$ of shellac were prepared by dissolving different weights of dewaxed bleached shellac in the required amount of $95 \% v / v$ ethanol using a magnetic stirrer (Stuart Overhead Stirrer Model SS20, Staffordshire, UK) with rotational speed at $60 \mathrm{rpm}$. To allow for a comparison of drying time and weight gain (Table 1), three replicates (samples) were produced.

2.11.2. Preparation of Nail Lacquers Containing Bitter Extract. The formulations containing either A. paniculata extract or T. crispa extract were performed as per formula delineated in Table 2. The mixture of shellac and bitter extract was dissolved in 95\% $v / v$ ethanol using a magnetic stirrer at a constant speed $60 \mathrm{rpm}$ for at least $6 \mathrm{~h}$ until well combined. After mixing, the total volume of mixture was adjusted to the final desired amount by adding 95\% $\mathrm{v} / \mathrm{v}$ ethanol. The homogeneities, viscosities, and bitterness intensities of formulations containing bitter extract are shown in Table 2.

\subsubsection{Development of Nail Lacquers Containing Bitter} Extract. The nail lacquers containing 20\% $w / w$ bitter extract and $20 \% \mathrm{w} / \mathrm{w}$ shellac in $95 \% v / v$ ethanol (formulation Nos. 7 and 19) were chosen for this study pursuant to their expected homogeneity, viscosity, and bitterness (Table 2). A study of a similar nail lacquer with added polypropylene glycol (PPG) in two concentrations $(5 \% \mathrm{w} / \mathrm{w}$ and $10 \% \mathrm{w} / \mathrm{w}$ ) showed that PG significantly reduced bitterness (data not shown). Nevertheless, PVP (polyvinylpyrrolidone) K-30 was used as a copolymer and cosolvent for enhancing the bitterness of nail lacquers and improving the solubility of bitter extracts. The formulation trials were carried out as per the formula described in Table 3. The mixture of shellac and PVP K-30 and the bitter extract were separately dissolved in $95 \% v / v$ ethanol in the required quantity using a
TABLE 1: Evaluation of drying time and weight gain of extract-free nail lacquers.

\begin{tabular}{lccc}
\hline $\begin{array}{l}\text { Film-forming } \\
\text { solution no. }\end{array}$ & $\begin{array}{c}\text { Concentrations of } \\
\text { shellac }(\% w / w)\end{array}$ & $\begin{array}{c}\text { Drying } \\
\text { time } \\
(\mathrm{min})\end{array}$ & Weight gain $(\mathrm{g})$ \\
\hline 1 & 10 & 15 & $0.0090 \pm 0.0010$ \\
2 & 15 & 16 & $0.0153 \pm 0.0006$ \\
3 & 20 & 17 & $0.0217 \pm 0.0025$ \\
4 & 25 & 21 & $0.0347 \pm 0.0067$ \\
5 & 30 & 26 & $0.0387 \pm 0.0064$ \\
\hline
\end{tabular}

magnetic stirrer with adjustable speed range of 50-60 rpm. Two resulting solutions were thoroughly mixed to ensure homogeneity and then made up to $100 \mathrm{~g}$ with $95 \% \mathrm{v} / \mathrm{v}$ ethanol. The developed nail lacquer was stirred until all parts of the solution were homogeneous and transferred to a tightly closed amber glass bottle with narrow mouth and plastic screw cap.

2.11.4. Physicochemical and Mechanical Evaluation of Developed Nail Lacquers [30]. Each prepared formulation was gently applied in the same direction on an acrylic fake nail with a brush. After hardening of a film at $25 \pm 1^{\circ} \mathrm{C}$ without any materials adhering to the finger, drying time and weight gain were determined. Drying time or dry-to-touch time was measured using a stopwatch. Weight gain measurements were carried out by weighing the samples to the nearest $0.0001 \mathrm{~g}$ with an analytical balance (Sartorius BP210S Electronic Balance, Sartorius Group, Göttingen, Germany) before and after applying formulations to each fake nail. The nail lacquer formulations were determined for their physical characteristics including homogeneity and color by visual inspection and $\mathrm{pH}$ values using a $\mathrm{pH}$ meter (SevenEasy, Mettler-Toledo, Switzerland). The viscosities of formulations were measured by using a Brookfield DV-III Ultra Programmable rheometer (Model RVDV-III Ultra, Brookfield engineering laboratories, Inc., Massachusetts, USA). All measurements were done in triplicate. A dial thickness gauge (Model G (0.01-10 mm), Peacock, Ozaki MFG. Co., Ltd., Tokyo, Japan) was used to measure dry film thickness. Tensile testing using a texture analyzer (TA.XT.plus, Stable Micro Systems Ltd., Surrey, UK) was performed to determine stress values of films formed by nail lacquers. The viscosity, $\mathrm{pH}$, drying time, weight gain, film thickness, and stress of each developed formulation are provided in Table 4.

The water resistance test was done by applying a tested nail lacquer onto a Teflon tray, leaving it to dry, peeling it off, cutting it to the same size, weighing each piece of film (known dry weight, $W_{o}$ ), placing the lacquer films in each testing basket, then immersing the baskets in distilled water at $25 \pm 1^{\circ} \mathrm{C}$ using a disintegration tester (ZTx20 series, Erweka $\mathrm{GmbH}$, Heusenstamm, Germany). The higher the percentage of the remaining weight in distilled water, the better the water resistance. In vitro bitterness release test was performed in simulated saliva $(\mathrm{pH} 6.8)$ at $37 \pm 1^{\circ} \mathrm{C}$ according to the above method. The lower the percentage 
TABLE 2: Composition, homogeneity, viscosity, and bitterness of nail lacquers containing bitter extract.

\begin{tabular}{|c|c|c|c|c|c|c|}
\hline \multirow{2}{*}{ Formulation no. } & \multicolumn{3}{|c|}{ Concentrations $(\% w / w)$} & \multirow{2}{*}{ Homogeneity* } & \multirow{2}{*}{ Viscosity* $^{*}$} & \multirow{2}{*}{ Bitterness* } \\
\hline & A. paniculata extract & T. crispa extract & Shellac & & & \\
\hline 1 & 10 & & 10 & +++ & + & + \\
\hline 2 & 10 & & 15 & ++ & ++ & ++ \\
\hline 3 & 10 & & 20 & ++++ & +++ & ++ \\
\hline 4 & 10 & & 25 & + & +++ & + \\
\hline 5 & 20 & & 10 & +++ & + & + \\
\hline 6 & 20 & & 15 & ++ & ++ & +++ \\
\hline 7 & 20 & & 20 & ++++ & +++ & ++++ \\
\hline 8 & 20 & & 25 & + & ++++ & ++ \\
\hline 9 & 30 & & 10 & Precipitation & + & + \\
\hline 10 & 30 & & 15 & Precipitation & ++ & + \\
\hline 11 & 30 & & 20 & Precipitation & +++ & + \\
\hline 12 & 30 & & 25 & Precipitation & ++++ & + \\
\hline 13 & & 10 & 10 & +++ & + & + \\
\hline 14 & & 10 & 15 & +++ & ++ & ++ \\
\hline 15 & & 10 & 20 & ++ & +++ & ++ \\
\hline 16 & & 10 & 25 & + & +++ & + \\
\hline 17 & & 20 & 10 & +++ & + & + \\
\hline 18 & & 20 & 15 & +++ & ++ & +++ \\
\hline 19 & & 20 & 20 & +++ & +++ & ++++ \\
\hline 20 & & 20 & 25 & + & ++++ & + \\
\hline 21 & & 30 & 10 & Precipitation & + & + \\
\hline 22 & & 30 & 15 & Precipitation & ++ & + \\
\hline 23 & & 30 & 20 & Precipitation & +++ & + \\
\hline 24 & & 30 & 25 & Precipitation & ++++ & + \\
\hline
\end{tabular}

*Grade offers four levels of quality: high (++++), moderate (+++), low (++), and very low (+).

TABLE 3: Composition of developed nail lacquers containing bitter extract and copolymer.

\begin{tabular}{lcccc}
\hline \multirow{2}{*}{$\begin{array}{l}\text { Formulation } \\
\text { no. }\end{array}$} & \multicolumn{3}{c}{ Concentrations $(\% w / w)$} & \\
& $\begin{array}{c}\text { A. paniculata } \\
\text { extract }\end{array}$ & $\begin{array}{c}\text { T. crispa } \\
\text { extract }\end{array}$ & Shellac & PVP \\
K-30 \\
\hline 7A & 20 & & 10 & 10 \\
7B & 20 & & 15 & 5 \\
19A & & 20 & 10 & 10 \\
19B & & 20 & 15 & 5 \\
\hline
\end{tabular}

of the remaining weight in simulated saliva, the greater the bitterness release. The dried lacquer film was weighed and dedicated as dry weight after testing $\left(W_{t}\right)$ in distilled water or simulated saliva, and then, the percentage of the remaining weight was calculated as illustrated in equation (1).

$$
\text { \%remaining weight }=\left(\frac{W_{t}}{W_{o}}\right) \times 100 \text {. }
$$

The percentages of the remaining weight obtained from water resistance and bitterness release tests are illustrated in Table 5.
2.11.5. Evaluation of Film Appearances and Bitterness Intensities in Human Volunteers. A total of 20 healthy participants (10 males and 10 females) ranging in age from 18 to 30 years volunteered to participate in the study. All of them were non-Muslims and had no prior history of allergic reactions to alcohol, food, medicines, natural extracts, and cosmetic ingredients. In addition, they were advised to steer clear of drinking (except water) and eating for a time no less than $1 \mathrm{~h}$ before starting the test. Each formulated nail lacquer was applied on participants' thumb nails once a day. After the nail lacquer had dried, participants evaluated the film appearances and bitterness intensities of nail lacquer films by finger touching, visualizing, and sucking, in line with their own perceptions and then answered questionnaires. Sensory assessments were performed in triplicate. The experimental protocol (REC 62.0912-038-4567) was approved by the Human Research Ethics Committee, Silpakorn University, Thailand.

2.11.6. Determination of Stability. The developed nail lacquers were stored individually in tightly closed amber glass containers. The physical stability of samples was evaluated by heat-cool cycling for six cycles between temperature of $4 \pm 1{ }^{\circ} \mathrm{C}$ and $45 \pm 1{ }^{\circ} \mathrm{C} / 75 \pm 2 \% \mathrm{RH}$ (relative humidity) with storage at each temperature for $24 \mathrm{~h}$. The samples were then analyzed for their $\mathrm{pH}$ values, viscosities, phase separation, 
TABLE 4: Physicochemical and mechanical properties of developed nail lacquers containing bitter extract and copolymer.

\begin{tabular}{lcccccc}
\hline Formulation no. & $\mathrm{pH}$ & Viscosity $(\mathrm{cP})$ & Drying time $(\mathrm{min})$ & Weight gain $(\mathrm{g})$ & Film thickness $(\mathrm{mm})$ & Stress $\left(\mathrm{N} / \mathrm{mm}^{2}\right)$ \\
\hline 7A & $5.09 \pm 0.02$ & $96.59 \pm 6.88$ & $8.00 \pm 1.00$ & $0.0234 \pm 0.0022$ & $0.9467 \pm 0.2210$ & $0.079 \pm 0.013$ \\
7B & $4.96 \pm 0.01$ & $45.34 \pm 4.72$ & $6.33 \pm 0.58$ & $0.0183 \pm 0.0022$ & $0.6483 \pm 0.1179$ & $0.136 \pm 0.047$ \\
19A & $4.66 \pm 0.02$ & $215.8 \pm 6.34$ & $10.67 \pm 1.15$ & $0.0488 \pm 0.0012$ & $0.7963 \pm 0.0132$ & $0.233 \pm 0.050$ \\
19B & $4.52 \pm 0.10$ & $101.04 \pm 3.64$ & $7.67 \pm 0.58$ & $0.0124 \pm 0.0007$ & $0.6417 \pm 0.0534$ & $0.553 \pm 0.255$ \\
\hline
\end{tabular}

TABLE 5: Percentages of the remaining weight of lacquer films after testing in distilled water (at $25 \pm 1^{\circ} \mathrm{C}$ ) and simulated saliva (at 37 $\left.\pm 1^{\circ} \mathrm{C}\right)$.

\begin{tabular}{|c|c|c|c|c|}
\hline \multirow[b]{2}{*}{$\begin{array}{l}\text { Formulation } \\
\text { no. }\end{array}$} & \multicolumn{2}{|c|}{$\begin{array}{c}\text { Water resistance test (in } \\
\text { distilled water) }\end{array}$} & \multicolumn{2}{|c|}{$\begin{array}{l}\text { Bitterness release test (in } \\
\text { simulated saliva) }\end{array}$} \\
\hline & $\begin{array}{c}\text { Percentages of } \\
\text { the remaining } \\
\text { weight }(\%)\end{array}$ & $\begin{array}{l}\text { Time } \\
(\min )\end{array}$ & $\begin{array}{l}\text { Percentages of } \\
\text { the remaining } \\
\text { weight }(\%)\end{array}$ & $\begin{array}{l}\text { Time } \\
(\min )\end{array}$ \\
\hline $7 \mathrm{~A}$ & $0.00 \pm 0.00$ & 180 & $0.00 \pm 0.00$ & 60 \\
\hline 7B & $58.60 \pm 12.37$ & 180 & $0.00 \pm 0.00$ & 40 \\
\hline $19 \mathrm{~A}$ & $10.86 \pm 11.88$ & 180 & $0.00 \pm 0.00$ & 60 \\
\hline 19B & $74.20 \pm 2.31$ & 180 & $0.00 \pm 0.00$ & 40 \\
\hline
\end{tabular}

and colors (Table 6). DPPH free radical scavenging and protein denaturation inhibitory activities of developed formulations were determined, before and after the stability test (Table 7). In addition, heavy metal concentrations and microbial loads in developed formulations were also examined.

2.12. Statistical Analysis. Experimental data is shown as mean \pm standard deviation (SD) of three independent experiments. Statistical significance $(p<0.05)$ was estimated by one-way analysis of variance (ANOVA) using SPSS 16.0. The Duncan's test was employed to measure specific differences between pairs of means.

\section{Results and Discussion}

\subsection{A. paniculata and T. crispa Ethanolic Extracts}

3.1.1. Extraction Yields and Chemical Constituents. The extraction yields of $A$. paniculata and T. crispa ethanolic extracts were $7.75 \pm 0.32 \% w / w$ and $3.50 \pm 0.23 \% w / w$, respectively. Appearances of $A$. paniculata and T. crispa ethanolic extracts were of dark greenish brown mass, as illustrated in Figure 2. Both extracts showed the presence of tannins, glycosides, reducing sugars, alkaloids, terpenoids, and flavonoids except steroids. However, saponins were found in A. paniculata extract but absent in T. crispa extract.

The structures of compounds in A. paniculata and $T$. crispa extracts were identified by comparing their FTIR spectra with previously reported data. The FTIR spectra of both extracts (Figure 3) showed broad bands (3418 and $\left.3413 \mathrm{~cm}^{-1}\right)$ in harmony with hydroxyl groups and medium bands (2928 and $2925 \mathrm{~cm}^{-1}$ ) and pairs of absorption bands (1631 and 1384 and 1644 and $1460 \mathrm{~cm}^{-1}$ ) in congruence with aromatic rings, thus suggesting that phytochemicals in both extracts were flavonoids. The FTIR spectrum of $A$. paniculata extract (Figure 3(a)) exhibiting peaks at 3418, 2928 and $2851,1750,1460$, and $1219 \mathrm{~cm}^{-1}$ may account for the presence of $\mathrm{O}-\mathrm{H}, \mathrm{C}-\mathrm{H}, \mathrm{C}=\mathrm{O}$, and $\mathrm{C}=\mathrm{C}$ stretching of an exo-methylene double bond and $\mathrm{C}-\mathrm{O}-\mathrm{C}$ stretching of a lactone ring, respectively, suggesting the presence of andrographolide (terpenoids) [31]. The FTIR spectrum of T. crispa extract (Figure 3(b)) displayed hydroxyl $\left(3413 \mathrm{~cm}^{-1}\right.$ with strong intensity and width), aromatic $\left(2925\right.$ and $\left.1460 \mathrm{~cm}^{-1}\right)$, carbonyl $\left(1711 \mathrm{~cm}^{-1}\right)$, and amide carbonyl $\left(1644 \mathrm{~cm}^{-1}\right)$ absorptions, characteristic of aporphine alkaloids [32]. The results of this study were consistent with several earlier investigations showing that terpenoids and alkaloids are the most common bitter compounds found in A. paniculata and $T$. crispa, respectively [9-11].

3.1.2. Total Phenolic Contents and Biological Activities of Bitter Extracts. The total phenolic contents of $A$. paniculata and T. crispa extracts were evaluated based on the standard curve of gallic acid $y=0.0296 x+0.0796 ; R^{2}=0.9997$. The total phenolic content of $T$. crispa extract $(64.43 \pm 3.77 \mathrm{mg}$ GAE/g dried extract) was found to be significantly higher $(p<0.05)$ than that of $A$. paniculata extract $(21.05 \pm 1.94$ mg GAE/g dried extract). A. paniculata and T. crispa extracts obtained with $95 \% v / v$ ethanol contained greater amounts of phenolic compounds than previously reported extracts prepared with $70 \% v / v$ methanol $(7.78 \mathrm{mg}$ GAE/g dried extract) [33] and $80 \% v / v$ ethanol $(29.83 \pm 2.14 \mathrm{mg}$ GAE/g dried extract) [34], respectively. Therefore, 95\% $v / v$ ethanol seemed to be an appropriate solvent for extraction of natural phenolics from A. paniculata and T. crispa.

The lower the $\mathrm{SC}_{50}$ value (concentration of extract required to scavenge $50 \%$ of DPPH radicals) and the higher FRAP value (capacity of extract to reduce ferric (III) ion to ferrous (II) ion) imply the higher the antioxidant activity. The results revealed that $T$. crispa extract with $\mathrm{SC}_{50}$ value of $116.15 \pm 2.40 \mu \mathrm{g} / \mathrm{ml}$ and FRAP value of $15.03 \pm 1.87 \mu \mathrm{g}$ AAE/g extract showed significantly stronger $(p<0.05)$ antioxidant activity than $A$. paniculata extract with $\mathrm{SC}_{50}$ value of $276.15 \pm 16.70 \mu \mathrm{g} / \mathrm{ml}$ and FRAP value of $4.05 \pm 0.35 \mu \mathrm{g}$ AAE/g extract, while ascorbic acid exhibited DPPH scavenging activity with $\mathrm{SC}_{50}$ value of $4.30 \pm 0.06 \mu \mathrm{g} / \mathrm{ml}$.

The lower value of albumin denaturation $\mathrm{IC}_{50}$ indicates the higher anti-inflammatory activity. It was observed that T. crispa extract with $\mathrm{IC}_{50}$ value of $0.90 \pm 0.01 \mathrm{mg} / \mathrm{ml}$ displayed significantly stronger $(p<0.05)$ anti-inflammatory activity than $A$. paniculata extract with $\mathrm{IC}_{50}$ value of 1.03 $\pm 0.16 \mathrm{mg} / \mathrm{ml}$, while diclofenac diethylamine is $0.68 \pm 0.00$ $\mathrm{mg} / \mathrm{ml}$ as a comparison. 
TABLE 6: $\mathrm{pH}$ values, viscosities, phase separation, sediment volumes, and colors of developed nail lacquers after six cycles of heating/cooling treatment.

\begin{tabular}{lcccc}
\hline Formulation no. & $\mathrm{pH}$ & Viscosity $(\mathrm{cP})$ & Phase separation & Color \\
\hline 7A & $5.07 \pm 0.01$ & $85.90 \pm 9.41$ & No separation & Dark green \\
$7 \mathrm{~B}$ & $4.96 \pm 0.01$ & $31.07 \pm 9.20$ & No separation & Dark green \\
19A & $4.57 \pm 0.01$ & $179.97 \pm 12.44$ & No separation & Dark brown \\
19B & $4.52 \pm 0.01$ & $65.84 \pm 9.37$ & No separation & Dark brown \\
\hline
\end{tabular}

TABLE 7: DPPH free radical scavenging and protein denaturation inhibitory activities of developed nail lacquers before and after six cycles of heating/cooling treatment.

\begin{tabular}{|c|c|c|c|c|}
\hline \multirow{2}{*}{ Formulation no. } & \multicolumn{2}{|c|}{ DPPH radical scavenging $\mathrm{SC}_{50}$} & \multicolumn{2}{|c|}{ Albumin denaturation $\mathrm{IC}_{50}$} \\
\hline & Before & After & Before & After \\
\hline $7 \mathrm{~A}$ & $1.46 \pm 0.06 \mathrm{mg} / \mathrm{ml}$ & $2.11 \pm 0.07 \mathrm{mg} / \mathrm{ml}$ & $4.94 \pm 0.18 \mathrm{mg} / \mathrm{ml}$ & $5.03 \pm 0.20 \mathrm{mg} / \mathrm{ml}$ \\
\hline $7 \mathrm{~B}$ & $1.54 \pm 0.08 \mathrm{mg} / \mathrm{ml}$ & $2.34 \pm 0.10 \mathrm{mg} / \mathrm{ml}$ & $5.09 \pm 0.24 \mathrm{mg} / \mathrm{ml}$ & $5.18 \pm 0.27 \mathrm{mg} / \mathrm{ml}$ \\
\hline $19 \mathrm{~A}$ & $0.82 \pm 0.07 \mathrm{mg} / \mathrm{ml}$ & $1.92 \pm 0.04 \mathrm{mg} / \mathrm{ml}$ & $2.95 \pm 0.12 \mathrm{mg} / \mathrm{ml}$ & $5.13 \pm 0.24 \mathrm{mg} / \mathrm{ml}$ \\
\hline 19B & $0.89 \pm 0.09 \mathrm{mg} / \mathrm{ml}$ & $1.99 \pm 0.08 \mathrm{mg} / \mathrm{ml}$ & $3.06 \pm 0.17 \mathrm{mg} / \mathrm{ml}$ & $5.34 \pm 0.29 \mathrm{mg} / \mathrm{ml}$ \\
\hline Ascorbic acid & \multicolumn{2}{|c|}{$4.47 \pm 0.08 \mu \mathrm{g} / \mathrm{ml}$} & \multicolumn{2}{|c|}{ ND } \\
\hline Diclofenac diethylamine & \multicolumn{2}{|c|}{ ND } & \multicolumn{2}{|c|}{$0.69 \pm 0.01 \mathrm{mg} / \mathrm{ml}$} \\
\hline
\end{tabular}

ND: not determined.

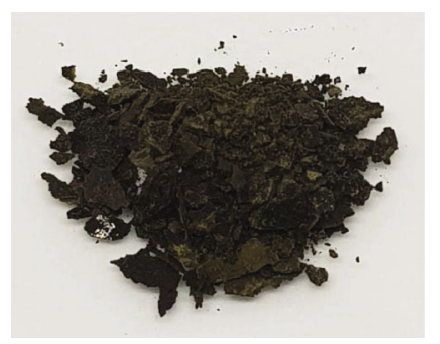

(a)

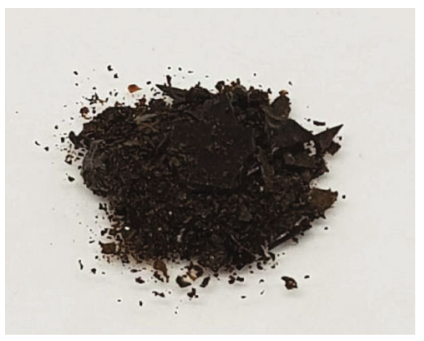

(b)

Figure 2: Ethanolic extracts of A. paniculata (a) and T. crispa (b).

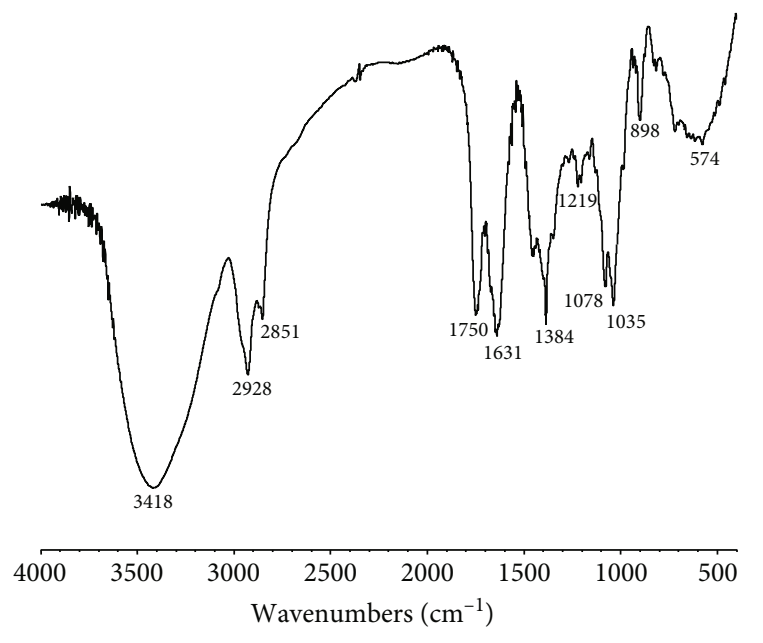

(a)

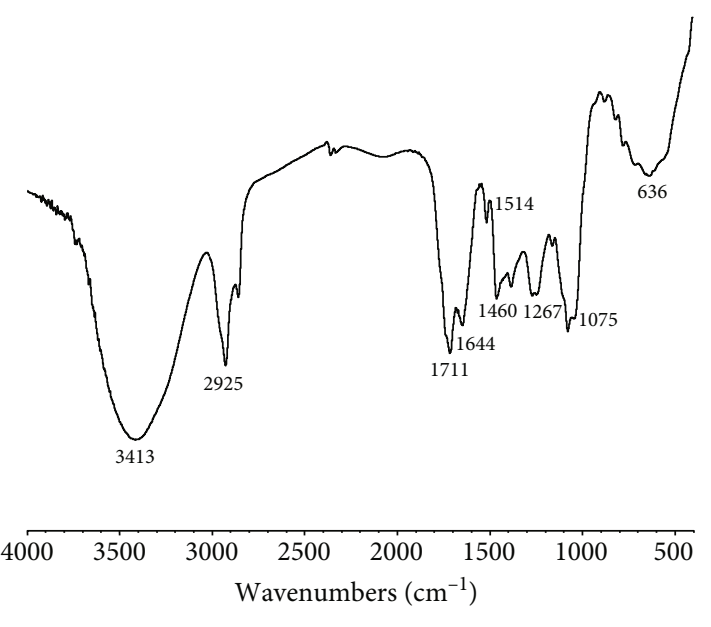

(b)

FIgURE 3: FTIR spectra of A. paniculata (a) and T. crispa extracts (b) in potassium bromide disc. 


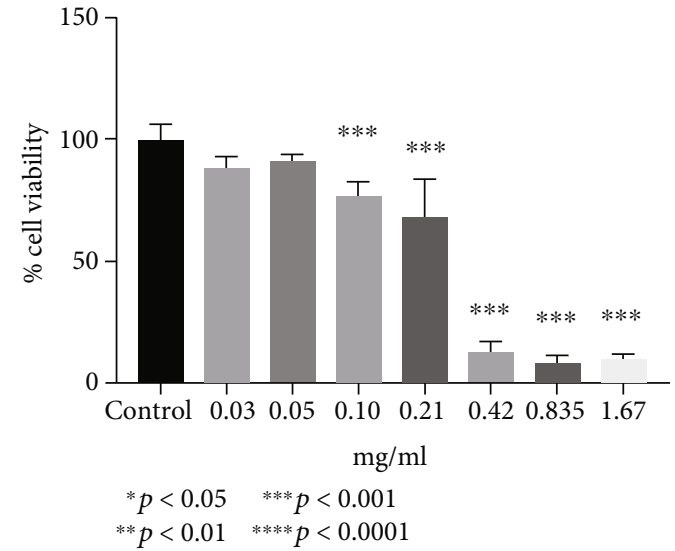

(a)

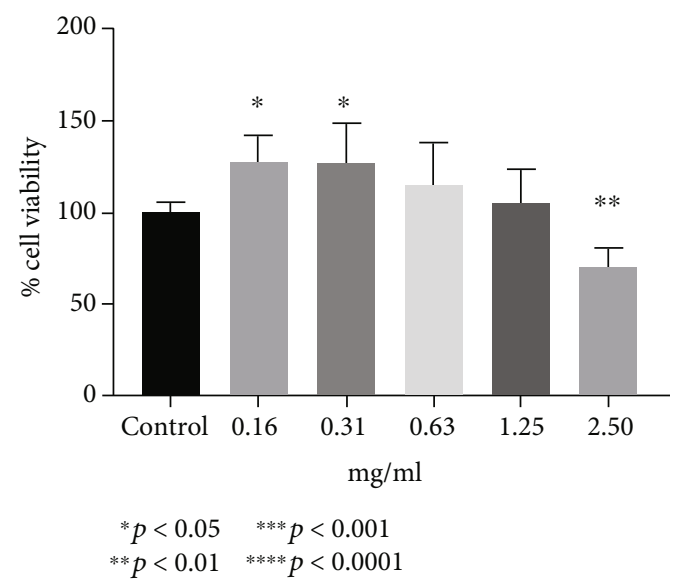

(c)

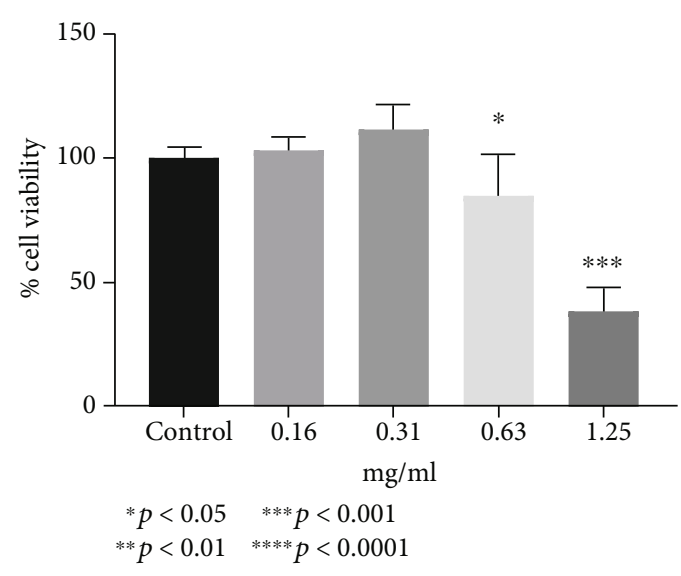

(b)

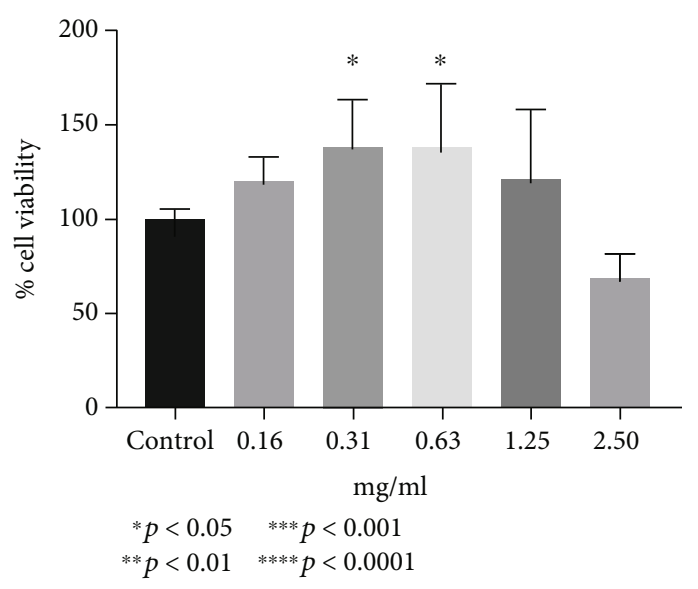

(d)

Figure 4: Percentages of CRL-2076 viability after $24 \mathrm{~h}$ incubation with A. paniculata extract (a), T. crispa extract (b), formulation No. $7 \mathrm{~A}$ (c), and formulation No. 19A (d). ${ }^{*} p<0.05,{ }^{* *} p<0.01,{ }^{* * *} p<0.001,{ }^{* * * *} p<0.0001$.

Many earlier studies showed the positive correlation between total phenolic content, antioxidant activity, and anti-inflammatory property [33-35]. In consistent with previous studies, the present study revealed that $T$. crispa extract with higher total phenolic content exhibited stronger antioxidant and anti-inflammatory activities than A. paniculata extract with lower total phenolic content.

3.1.3. Heavy Metals and Microbial Loads of Bitter Extracts. Maximum limits of $\mathrm{Hg}(1 \mathrm{mg} / \mathrm{kg}), \mathrm{Pb}(20 \mathrm{mg} / \mathrm{kg})$, As $(5 \mathrm{mg} / \mathrm{kg})$, and $\mathrm{Cd}(5 \mathrm{mg} / \mathrm{kg})$ in cosmetics have been set by Association of South East Asian Nations (ASEAN) guidelines [36]. The concentrations of $\mathrm{Pb}$ and $\mathrm{Cd}$ in $\mathrm{A}$. paniculata extract were $0.010 \pm 0.001 \mathrm{mg} / \mathrm{kg}$ and $0.002 \pm 0.002 \mathrm{mg} / \mathrm{kg}$, respectively, but $\mathrm{Hg}$ and As were not detected. The heavy metal concentrations found in $T$. crispa extract were $\mathrm{Hg}=$ $0.002 \pm 0.002 \mathrm{mg} / \mathrm{kg}, \mathrm{Pb}=0.010 \pm 0.009 \mathrm{mg} / \mathrm{kg}$, and $\mathrm{Cd}=$ $0.001 \pm 0.003 \mathrm{mg} / \mathrm{kg}$, but As was not found. The concentrations of heavy metals in both extracts were below the permissible values.

ASEAN microbiological limits in products for children under 3 years; eye area and mucous membranes were total aerobic mesophilic microorganisms not more than $500 \mathrm{cfu} /$ $\mathrm{g}$ and specified pathogens including P. aeruginosa, S. aureus, and C. albicans absent in $0.1 \mathrm{~g}$ of test sample [36]. Owing to Thailand local concerns, the extracts performed that the additional test for Clostridium spp., A. paniculata, and T. crispa extracts showed total aerobic mesophilic microorganisms below $10 \mathrm{cfu} / \mathrm{g}$, but all specified pathogens including $P$. aeruginosa, S. aureus, C. albicans, and Clostridium spp. were not detected in any of the samples analyzed. The results were consistent with the microbiological requirements. In conclusion, both extracts were safe from harmful heavy metals and pathogens.

3.1.4. Cytotoxicity of Bitter Extracts. This experiment was performed to assess the cytotoxic activities of bitter extracts at various concentrations on CRL-2076 human dermal fibroblasts. The percentages of cell viability upon $24 \mathrm{~h}$ treatments with $A$. paniculata and T. crispa extracts are illustrated in Figures 4(a) and 4(b), respectively. The viability of cells treated with A. paniculata $(0.05 \mathrm{mg} / \mathrm{ml})$ and T. crispa $(0.63 \mathrm{mg} / \mathrm{ml})$ extracts was not significantly different from the control. Their \% survival values were $92 \%$ and $83 \%$, respectively. Thus, the results showed that A. paniculata and $T$. crispa extracts at the concentration ranges of $0.03-0.05 \mathrm{mg} /$ $\mathrm{ml}$ and $0.16-0.63 \mathrm{mg} / \mathrm{ml}$, respectively, exhibited low levels of cytotoxicity upon $24 \mathrm{~h}$ incubation. 


\subsection{Developed Nail Lacquers}

3.2.1. Formulation Development of Nail Lacquers. The extract-free nail lacquers were prepared by dissolving shellac in $95 \% v / v$ ethanol to obtain film-forming solutions in the concentration range of $10-30 \% w / w$. As delineated in Table 1, the shellac concentration affects the drying time and weight gain. The results revealed that the higher the shellac concentration, the longer the drying time, the greater the weight gain. Film-forming solution No. 5 composed of shellac concentration up to $30 \% \mathrm{w} / \mathrm{w}$ produced a very thick film with the highest weight gain that was prone to peeling. Furthermore, its drying time was too long, and it was too viscous to apply. Therefore, film-forming solution No. 5 was cut off from the next experiment.

The nail lacquers containing A. paniculata extract (formulation Nos. 1-12) and T. crispa extract (formulation Nos. 13-24) were performed by a simple mixing technique, and their homogeneities, viscosities, and bitterness intensities were evaluated at room temperature. The results are depicted in Table 2 which shows that the formulation Nos. 9-12 and Nos. 21-24 containing 30\% $w / w$ extract were precipitated after observing at $25 \pm 1^{\circ} \mathrm{C}$ for one night. In addition, the other formulations (Nos. 1-6 and 8 and Nos. 13-18 and 20) exhibited unfavorable homogeneity, viscosity, or bitterness. However, the results also showed that the formulation No. 7 and No. 19 containing 20\% w/w bitter extract and $20 \% \mathrm{w} / \mathrm{w}$ shellac were the most bitter nail lacquers with good homogeneity and suitable viscosity. Consequently, the formulation No. 7 and No. 19 were selected for further studies by adding $(+10 \% w / w$ or $+5 \% w / w$ PVP K-30) and subtracting (-10\% $w / w$ or $-5 \% w / w$ shellac) of the nail lacquer composition (Table 3 ) to obtain the formulation Nos. 7A and 7B and 19A and 19B, respectively. Formulations contained PVP K-30 which acts as a copolymer and solubilizer to improve mechanical property of shellac film and enhance the solubility of bitter extract, respectively.

3.2.2. Physicochemical and Mechanical Evaluation of Developed Nail Lacquers. Table 4 shows physicochemical and mechanical properties of formulation Nos. 7A and 7B and $19 \mathrm{~A}$ and $19 \mathrm{~B}$ which were developed from formulation Nos. 7 and 19, respectively. All formulations had $\mathrm{pH}$ values between $4.52 \pm 0.10$ and $5.09 \pm 0.02(p<0.05)$, and their $\mathrm{pH}$ values were not affected by the type of extract and the ratio of shellac: PVP K-30. The viscosities of all developed formulations except No. 7B ranged approximately between 100 and $220 \mathrm{cPs}$, indicating a highly glossy film likely owing to a smooth surface [37]. Additionally, this viscosity range came up with good adherence and flow property. The formulation No. 7A and No. 19A containing 10\% $w / w$ shellac and $10 \% w / w$ PVP K-30 possessed higher viscosity values $(96.59 \pm 6.88 \mathrm{cPs}$ and $215.8 \pm 6.34 \mathrm{cPs})$ than the formulation No. 7B and No. 19B containing 15\% $w / w$ shellac and 5\% $w / w$ PVP K-30 $(45.34 \pm 4.72 \mathrm{cPs}$ and $101.04 \pm 3.64 \mathrm{cPs})$, respectively. It indicates the impact of polymer ratio (shellac: PVP K-30) on the viscosity of nail lacquers.
Furthermore, the average values of drying time, weight gain, and film thickness of formulation No. 7A and No. 19A were greater than those of formulation No. 7B and No. 19B, respectively (Table 4). Drying times of nail lacquers should be less than $10 \mathrm{~min}$ and vary depending on the volatility characteristics of their solvent systems used in the formulations [38]. The drying times for all developed nail lacquers were between $6.33 \pm 0.58$ and $10.67 \pm 1.15 \mathrm{~min}$. Nevertheless, the formulation No. 19A had a slightly longer drying time $(10.67 \pm 1.15 \mathrm{~min})$ than the criterion. Weight gain, the weight of the residual film after solvent evaporation, indicates the nonvolatile content [38]. It was seen that as the PVP K-30 concentration increases from $5 \% w / w$ to $10 \% w / w$ and the shellac concentration decreases from $15 \% w / w$ to $10 \% w / w$ the weight gain increases (Tables 3 and 4). The results revealed that nonvolatile content of nail lacquers varied depending on the type and concentration of polymer used. The thicknesses of the films obtained from all developed formulations were varied in the range between $0.6417 \pm 0.0534$ and $0.9467 \pm 0.2210 \mathrm{~mm}$ (Table 4). The thickness of film was found to be consistent for all formulations. It can be concluded that the variation of film thicknesses was solely affected by the ratio of shellac: PVP K-30 and the amount of herbal extract employed in nail lacquers. The results also revealed that film thickness decreased as the percentage of shellac increased, perhaps because of the lower solid contents of shellac [19] and T. crispa extract compared to PVP K-30 and A. paniculata extract, respectively. The film obtained from the formulation No. 7A $(20 \% w / w A$. paniculata extract, $10 \% \mathrm{w} / \mathrm{w}$ shellac, and $10 \% \mathrm{w} / \mathrm{w}$ PVP K30) had the greatest thickness value $(0.9467 \pm 0.2210 \mathrm{~mm})$.

Tensile strength designated as a stress is estimated as units of applied force per area $\left(\mathrm{N} / \mathrm{mm}^{2}\right)$. Measured stress values of films derived from developed nail lacquers ranged from $0.079 \pm 0.013$ to $0.553 \pm 0.255 \mathrm{~N} / \mathrm{mm}^{2}$ (Table 4). The film stress increased with increasing the proportion of shellac (Tables 3 and 4). If film stress is too high, it can lead to film cracking [39]. Accordingly, lower stress value might possibly lead to higher mechanical flexibility of films. The formulation No. 7A and No. 19A having a lower percentage of shellac and higher percentage of PVP K-30 as compared with the formulation No. 7B and No. 19B, respectively, exhibited significantly lower stress values (Table 4). The result indicated that PVP K-30 added to compensate for the lower percentage of shellac could improve the flexibility of films by reducing stress values.

Water resistance test was performed in distilled water. It could be seen that an increase in the concentration of shellac and a decrease in the concentration of PVP K-30 would lead to an increase in the water resistance as depicted in Tables 3 and 5. Formulation No. 7B and No. 19B displayed higher water resistance as compared with formulation No. 7A and No. 19A, respectively. The nail lacquer films disclosed a slow deterioration during $180 \mathrm{~min}$, except for formulation No. 7A which was quickly eroded in distilled water. It seems reasonable to assume that the formulation No. 7B and No. 19B $(20 \% \mathrm{w} / \mathrm{w}$ bitter extract, $15 \% \mathrm{w} / \mathrm{w}$ shellac, and 5\% $w / w$ PVP K-30) showed much better resistance to water wash out than formulation No. 7A and No. 19A $(20 \% w / w$ bitter 
extract, $10 \% w / w$ shellac, and 10\% $w / w$ PVP K-30), respectively. Although the formulation No. 7A was the least waterresistant nail lacquer (remaining weight $0.00 \pm 0.00 \%$ ), it was able to withstand distilled water for up to $180 \mathrm{~min}$ that fell within acceptable criteria.

Bitterness release test was conducted in simulated salivary fluid pH6.8, and the results are illustrated in Table 5 which shows that the rapid disintegration and fast release of bitter extract were observed in the case of formulation No. 7B and No. 19B (remaining weight $0.00 \pm 0.00 \%$ for $40 \mathrm{~min})$. The extract contained in the films composed of $15 \% w / w$ shellac and 5\% $w / w$ PVP K-30 took about $40 \mathrm{~min}$ for the complete dissolution, resulting in a faster dissolution as compared with those composed of $10 \% \mathrm{w} / \mathrm{w}$ shellac and $10 \% w / w$ PVP K-30 (remaining weight $0.00 \pm$ $0.00 \%$ for $60 \mathrm{~min}$ ). The results revealed that formulation No. 7A and No. 19A were gradually released the bitter substance for a prolonged period.

The results of the physicochemical and mechanical evaluation indicated that nail lacquer formulation No. 19A and No. 19B were not suitable for further evaluation by volunteers, for the following reasons. The nail lacquer formulation No. 19A was too viscous with the highest viscosity $(215.8 \pm 6.34 \mathrm{cPs})$ and took too long to dry with the longest drying time $(10.67 \pm 1.15 \mathrm{~min})$. Furthermore, the film derived from the formulation No.19A had too much solid content with the greatest weight gain $(0.0488 \pm 0.0012 \mathrm{~g})$. The highest film stress value obtained from the formulation No. 19B was high enough to cause cracking $(0.553 \pm 0.255$ $\mathrm{N} / \mathrm{mm}^{2}$ ). Accordingly, the nail lacquer formulation Nos. $7 \mathrm{~A}$ and $7 \mathrm{~B}$ were selected for volunteer evaluation.

3.2.3. Evaluation of Film Appearances and Bitterness Intensities in Human Volunteers. The selected nail lacquers including formulation Nos. 7A and 7B were assessed in 20 healthy volunteers by applying on the nail plates of the left and right thumbs, respectively. After the nail lacquer had dried, volunteers evaluated the film characteristics including smoothness, glossy, color, and adhesiveness by finger touching and visualizing. After that, they sucked their thumbs and maintained the bitter solutions in their mouths for $5 \mathrm{~s}$ to estimate the bitterness intensity. All volunteers completed this study and reported no side effects caused by nail lacquers. Eighty-five percent of the volunteers reported that the formulation No. 7A was more bitter than the formulation No. 7B while seventy-five percent of the volunteers found that the film of formulation No.7B presented better film characteristic than that of formulation No. 7A.

3.2.4. Cytotoxicity of Developed Nail Lacquers. Because of their greater bitterness, the cytotoxicity assay was performed for formulation No. 7A and No. 19A. These developed nail lacquers were screened for their cytotoxic activities against CRL-2076 human dermal fibroblasts at different concentrations to determine the viability by MTT assay. The cell survival upon treatments of the formulations are depicted in Figures 4(c) and 4(d). Formulation No. 7A and No. 19A at the concentration up to $1.25 \mathrm{mg} / \mathrm{ml}$ did not show toxicity to the cells within $24 \mathrm{~h}$ of exposure. These results indicate the nontoxic nature of formulation Nos. 7A and 19A.

\subsubsection{Heavy Metals and Microbial Loads of Developed Nail} Lacquers. The contents of $\mathrm{Pb}(0.001 \pm 0.004 \mathrm{mg} / \mathrm{kg})$ and $\mathrm{Cd}$ $(0.001 \pm 0.005 \mathrm{mg} / \mathrm{kg})$ in developed formulations were lower than the permissible limits of ASEAN guidelines for cosmetics [36] while $\mathrm{Hg}$ and As were not detected. Total aerobic mesophilic microorganisms and specified pathogens of developed formulations were within ASEAN microbiological limits. Therefore, all developed nail lacquers were found to be safe and acceptable, especially in children.

3.2.6. Stability Studies. The stability studies were obtained to find out the alteration of $\mathrm{pH}$ values, viscosities, phase separation, colors, and biological activities. The results are shown in Tables 6 which indicates that there were no major changes in physical appearances and $\mathrm{pH}$ values except for a significant decrease in viscosities. After six cycles of heating/cooling stability testing, the developed nail lacquers clumped into precipitates, but they were more uniformly distributed after hand-shaking. Therefore, all developed formulations might require gentle shaking before use.

DPPH free radical scavenging and protein denaturation inhibitory activities of developed formulations subjected to accelerated stability were investigated and compared with freshly prepared nail lacquers. The results obtained are detailed in Table 7. All developed formulations showed significant increase $(p<0.05)$ in DPPH radical scavenging $\mathrm{SC}_{50}$ and albumin denaturation $\mathrm{IC}_{50}$ without exhibiting microbial growth on the investigation. Even though their biological activities and viscosities were reduced, they were within the acceptable ranges. The results of stability studies showed that there were no serious stability problems of all developed formulations. The recommended storage condition for the developed formulations was $4^{\circ} \mathrm{C}$ in order to preserve their biological activities.

\section{Conclusion}

Anti-nail-biting lacquers containing bitter herbal extracts were successfully prepared using shellac and PVP K-30 as film formers. Formulation No. 7A containing 20\% $w / w A$. paniculata extract, $10 \% \mathrm{w} / \mathrm{w}$ shellac, and $10 \% \mathrm{w} / \mathrm{w}$ PVP K30 was the most appropriate formulation in relation to preventing nail biting. A. paniculata and T. crispa extracts loaded in formulations at $20 \% \mathrm{w} / \mathrm{w}$ possessed antioxidant and anti-inflammatory properties, harmonizing the traditional medicine practice. After six cycles of heating/cooling treatment, the analysis of all developed formulations has revealed the existence of biological activities. Moreover, all developed formulations had gratifying appearances with consistency and without the tendency of separation. The innovative anti-nail-biting lacquer mainly composed of herbal extract and shellac was not only without toxic chemicals but also with antioxidant and anti-inflammatory substances. 


\section{Data Availability}

The data employed to support the findings of this study are contained in the article. The other data are available from the corresponding author upon request.

\section{Disclosure}

A preprint has previously been published [40].

\section{Conflicts of Interest}

All researchers state that there are no conflicts of interest.

\section{Acknowledgments}

This research was kindly supported by the Faculty of Pharmacy, Silpakorn University, Product Development Project under Innovative House by the Thailand Science Research and Innovation (TSRI), the National Science and Technology Development Agency (NSTDA), the National Research Council of Thailand (NRCT) (grant number RUG6250035), and H. A. Plus (Thailand) Co., Ltd.

\section{Supplementary Materials}

Figure S1: formulation No. 7A containing A. paniculata extract at $1 \% w / w(\mathrm{~A}), 10 \% w / w(\mathrm{~B})$, and $20 \% w / w(\mathrm{C})$. Figure S2: formulation No. 19A containing T. crispa extract at $1 \% w / w(\mathrm{~A}), 10 \% w / w(\mathrm{~B})$, and $20 \% w / w(\mathrm{C})$. Figure S3: sensory evaluation form (Supplementary Materials). (Supplementary Materials)

\section{References}

[1] A. Ghanizadeh, "Nail biting; etiology, consequences and management," International Journal of Molecular Sciences, vol. 36, no. 2, pp. 73-79, 2011.

[2] P. Halteh, R. K. Scher, and S. R. Lipner, "Onychophagia: a nailbiting conundrum for physicians," Journal of Dermatological Treatment, vol. 28, no. 2, pp. 166-172, 2017.

[3] R. B. Sah, I. S. Paudel, R. Baral, P. Poudel, N. Jha, and P. K. Pokharel, "A study of prevalence of intestinal protozoan infections and associated risk factors among the school children of Itahari, eastern region of Nepal," Journal of Computer-Mediated Communication, vol. 3, no. 1, pp. 32-36, 2013.

[4] F. G. Kamal and R. A. Bernard, "Influence of nail biting and finger sucking habits on the oral carriage of Enterobacteriaceae," Contemporary Clinical Dentistry, vol. 6, no. 2, pp. 211214, 2015

[5] O. A. Idowu, O. Babatunde, T. Soniran, and A. Adediran, "Parasitic infections in finger-sucking school age children," Pediatric Infectious Disease Journal, vol. 30, no. 9, pp. 791-792, 2011.

[6] G. Koritzky and E. Yechiam, "On the value of nonremovable reminders for behavior modification: an application to nailbiting (onychophagia)," Behavior Modification, vol. 35, no. 6, pp. 511-530, 2011.

[7] U S Department of Health \& Human Services, U S Food and Drug Administration, CFR-Codeg of Federal Regulations Title
21, 21(5), New Hampshire Avenue Silver Spring, MD 20993 , 2019.

[8] D. D. Patadia and D. R. Stukus, "Thumb-sucking, nail-biting, and atopic sensitization, asthma, and hay fever," Pediatrics, vol. 140, Supplement 3, pp. S180-S181, 2017.

[9] M. A. B. Nyeem, M. A. Mannan, M. Nuruzzaman, K. M. Kamrujjaman, and S. K. Das, "Indigenous king of bitter (Andrographis paniculata): a review," Journal of Medicinal Plants Studies, vol. 5, no. 2, pp. 318-324, 2017.

[10] E. Mussard, S. Jousselin, A. Cesaro et al., "Andrographis paniculata and its bioactive diterpenoids against inflammation and oxidative stress in keratinocytes," Antioxidants, vol. 9, no. 6, p. 530, 2020.

[11] W. Ahmad, I. Jantan, and S. N. A. Bukhari, "Tinospora crispa (L.) Hook. f. \& Thomson: a review of its ethnobotanical, phytochemical, and pharmacological aspects," Frontiers in Pharmacology, vol. 7, p. 59, 2016.

[12] P. Rich, "Nail cosmetics," Dermatologic Clinics, vol. 24, no. 3, pp. 393-399, 2006.

[13] I. Šveikauskaité and V. Briedis, "Effect of film-forming polymers on release of naftifine hydrochloride from nail lacquers," International Journal of Polymer Science, vol. 2017, Article ID 1476270, 7 pages, 2017.

[14] J. Jefferson and P. Rich, "Update on nail cosmetics," Dermatologic Therapy, vol. 25, no. 6, pp. 481-490, 2012.

[15] Z. D. Draelos, "Cosmetic treatment of nails," Clinics in Dermatology, vol. 31, no. 5, pp. 573-577, 2013.

[16] N. A. Madnani and K. J. Khan, "Nail cosmetics," Indian Journal of Dermatology, Venereology and Leprology, vol. 78, no. 3, pp. 309-317, 2012.

[17] R. Lazzarini, M. F. S. Hafner, A. S. A. Lopes, and C. B. Oliari, "Allergy to hypoallergenic nail polish: does this exist?," Anais Brasileiros de Dermatologia, vol. 92, no. 3, pp. 421-422, 2017.

[18] A. S. Young, J. G. Allen, U. Kim et al., "Phthalate and organophosphate plasticizers in nail polish: evaluation of labels and ingredients," Environmental Science \& Technology, vol. 52, no. 21, pp. 12841-12850, 2018

[19] D. Panchapornpon, C. Limmatvapirat, J. Nunthanid et al., "Development of shellac from source of Thailand as an alternative polymer for postharvest treatment," Thai Journal of Agricultural Science, vol. 44, no. 5, pp. 224-229, 2011.

[20] A. Perveen, N. Jahan, W. Abdul, and M. T. Alam, "Methods of processing of lac (Laccifer lacca Kerr) described in Unani system of medicine," Research Journal of Pharmaceutical Sciences, vol. 2, no. 8, pp. 5-7, 2013.

[21] The BGO plant database, the Botanical Garden Organization, "Ministry of Natural Resource and Environment, Thailand," http://www.qsbg.org/database/plantdb/mdp/index.asp.

[22] T. T, A. R, V. D, and D. R, "Preliminary phytochemical screening of different solvent mediated medicinal plant extracts evaluated," International Research Journal of Pharmacy, vol. 6, no. 4, pp. 246-248, 2015.

[23] T. M. B. Bandiola, "Extraction and qualitative phytochemical screening of medicinal plants: a brief summary," International Journal of Pharmaceutics, vol. 8, no. 1, pp. 137-143, 2018.

[24] S. P. Dash, S. Dixit, and S. Sahoo, "Phytochemical and biochemical characterizations from leaf extracts from Azadirachta Indica: an important medicinal plant," Biochemistry \& Analytical Biochemistry, vol. 6, no. 2, article 1000323, p. 4, 2017. 
[25] D. R. Hebbar and M. S. Nalini, "Evaluation of phytochemicals, total phenolics and antioxidant activities of Schefflera spp. (Araliaceae) from southern India," Journal of Pharmacognosy and Phytochemistry, vol. 2, no. 5, pp. 10-14, 2014.

[26] W. Krongrawa, S. Limmatvapirat, N. Pongnimitprasert, P. Meetam, and C. Limmatvapirat, "Formulation and evaluation of gels containing coconut kernel extract for topical application," Asian Journal of Pharmaceutical Sciences, vol. 13, no. 5, pp. 415-424, 2018.

[27] W. Krongrawa, S. Limmatvapirat, S. Saibua, and C. Limmatvapirat, "Effects of gamma irradiation under vacuum and air packaging atmospheres on the phytochemical contents, biological activities, and microbial loads of Kaempferia parviflora rhizomes," Radiation Physics and Chemistry, vol. 173, article 108947, p. 8, 2020.

[28] The United States Pharmacopeial Convention, “<61> Microbiological examination of nonsterile products: microbial enumeration tests," in The United States Pharmacopeia, 41st rev., and the national formulary. 36th ed, The United States Pharmacopeial Convention, Rockville (MD), 2018.

[29] T. L. Riss, R. A. Moravec, A. L. Niles et al., "Cell viability assays," in Assay Guidance Manual, G. S. Sittampalam, N. P. Coussens, K. Brimacombe, A. Grossman, M. Arkin, D. Auld, C. Austin, J. Baell, B. Bejcek, and J. M. M. Caaveiro, Eds., Eli Lilly \& Company and the National Center for Advancing Translational Sciences; Bethesda, MD, USA, Rockville, MD, USA, 2004.

[30] K. Yadav, J. N. Mishra, and D. K. Vishwakarma, "Formulation and development of antifungal nail lacquer containing miconazole nitrate use in treatment of onychomycosis," International Journal of Scientific and Research Publications, vol. 9, no. 4, pp. 736-752, 2019.

[31] Y. Syukri, R. Martien, E. Lukitaningsih, and A. E. Nugroho, "Quantification of andrographolide isolated from Andrographis paniculata Nees obtained from traditional market in Yogyakarta using validated HPLC," Indonesian Journal of Chemistry, vol. 16, no. 2, pp. 190-197, 2016.

[32] M. I. Choudhary, M. Ismail, Z. Ali, K. Shaari, N. H. Lajis, and Atta-ur-Rahman, "Alkaloidal constituents of Tinospora crispa," Natural Product Communications, vol. 5, no. 11, pp. 1747-1750, 2010.

[33] L. Md Salleh, H. Hartati, R. Jamaludin, M. A. Che Yunus, H. Yakub, and A. A. Aziz, "Antioxidant activity and total phenolic contents in methanol extracts from Swietenia mahagoni and Andrographis paniculata," Jurnal Teknologi, vol. 69, no. 4, pp. 51-53, 2014.

[34] J. Tuekaew, N. Siriwatanametanon, Y. Wongkrajang, R. Temsiririrkkul, and I. Jantan, "Evaluation of the antioxidant activities of Ya-hom Intajak, a Thai herbal formulation, and its component plants," Tropical Journal of Pharmaceutical Research, vol. 13, no. 9, pp. 1477-1485, 2014.

[35] G. A. Shallangwa, P. A. Ekwumemgbo, U. I. Osu, O. O. Bolarin, and A. Moyosore, "Total phenolic, flavonoid contents and in-vitro anti-inflammation evaluation of ethanol extracts of Hibiscus sabdariffa calyx, Malus domestica and their 1:1 extracts blend on protein denaturation," Algerian Journal of Natural Products, vol. 5, no. 2, pp. 483-491, 2017.

[36] “The 26th ASEAN cosmetic scientific body (ACSB) meeting $2^{\text {nd }}-3^{\text {rd }}$ May 2017, Siem Reap, Cambodia and endorsed at the $26^{\text {th }}$ ASEAN cosmetic committee (ACC) meeting $4^{\text {th }}-$ $5^{\text {th }}$ May 2017, Siem Reap, Cambodia. Association of South East Asian Nations (ASEAN) guidelines on limits of contami- nants for cosmetics," 2017, December 2020, https://asean.org/ wp-content/uploads/2012/05/ASEAN-Guidelines-Limits-ofContaminant-Cosmetics-.pdf.

[37] R. Manavalan Barish, E. A. Theodore, Aswanivm, and R. Venkatanarayanan, "Formulation and evaluation of a medicated nail lacquer for the treatment of onychomycosis," International Journal of Research in Pharmaceutical and Nano Sciences, vol. 5, no. 4, pp. 201-211, 2016.

[38] R. Chandra, S. Kumar, and A. Aggarwal, "Evaluation of nail lacquer," Indo Global Journal of Pharmaceutical Sciences, vol. 2, no. 4, pp. 379-382, 2012.

[39] M. Luangtana-anan, S. Limmatvapirat, J. Nunthanid, C. Wanawongthai, R. Chalongsuk, and S. Puttipipatkhachorn, "Effect of salts and plasticizers on stability of shellac film," Journal of Agricultural and Food Chemistry, vol. 55, no. 3, pp. 687-692, 2007.

[40] C. Limmatvapirat, S. Limmatvapirat, S. Chansatidkosol et al., "Extraction, biological activity, formulation, and evaluation of bitter herbs as anti-nail-biting lacquers," Research Square, vol. 1, 2021 https://www.researchsquare.com/article/rs$763704 / \mathrm{v} 1$. 